\title{
Anti-Fertility Agents- Estrogens
}

\section{Revathi $\mathrm{B}^{1 *}$ and Prashanth $\mathrm{K}^{2}$}

${ }^{1}$ Pharmaceutical Chemistry, Osmania University, Hyderabad, Telangana, India

${ }^{2}$ Mechanical Engineering, JNTU, Hyderabad, Telangana, India

\begin{abstract}
Estrogens are the primary female sex organs which can be either natural steroidal or synthetic non-steroidal. This group of compounds has their importance in menstrual and estrous reproductive cycles. They are basically used as oral contraceptives. Also as estrogen replacement therapy and in hormone replacement therapy for postmenopausal women and trans women respectively. Contraception is the method of preventing normal process of ovulation, fertilization and ovum implantation nothing but pregnancy. Oestrogens are synthesized by the ovary and placenta and in small amounts by the testis and adrenal cortex. As for other steroids, the starting substance for oestrogen synthesis is cholesterol. As such many anti-fertility agents have been developed as it is the need of hour in today's living scenario.
\end{abstract}

Keywords: Anti fertility agents, androgens, Oestrogens, Cholestrol, Contraceptive agents.

\section{Introduction}

Drugs which used for preventing fertilization are called as antifertility agents. These are also known as contraceptive agents. Contraception is the method of preventing normal process of ovulation, fertilization and ovum implantation nothing but pregnancy [1-3]. Estrogens are the primary female sex organs which can be either natural steroidal or synthetic non-steroidal. This group of compounds has their importance in menstrual and estrous reproductive cycles. They are basically used as oral contraceptives. Also as estrogen replacement therapy and in hormone replacement therapy for post-menopausal women and trans women respectively [4,5]. Estrogens are synthesized in vertebrates as well as some insects. This presence of the female sex hormones $\mathrm{n}$ insects and vertebrates suggests that they have an ancient evolutionary history. Under certain circumstances, they are used in males for treatment of prostate cancer. Estrogens are also known to promote wound healing [6].

\section{Classification}

These are classified into two types.

1. Female contraceptive agents

2. Male contraceptive agents

\section{Female contraceptive agents}

These are available as oral, injectable, and transdermal patches. Oral contraceptive agents include both steroidal and non-steroidal agents and also available in chemical, mechanical and surgical dosage forms.

a. Steroidal oral contraceptive agents:

Oestrogens: Ethinyl Oestradiol, Mestranol.

Progesterones: Norethindrone, Norethynodrel, Levonorgestrel, Norgestrel.

b. Non steroidal oral contraceptive agents:

Diethyl Stilbestrol, dienestrol.

\section{Male contraceptive agents}

a. Steroidal contracptive agents:

E.g. Testosterone enanthate, levonorgestrel. b. Non steroidal agents:

E.g. Gossypol

\section{OESTROGENS}

Oestrogens are synthesized by the ovary and placenta and in small amounts by the testis and adrenal cortex. As for other steroids, the starting substance for oestrogen synthesis is cholesterol. The immediate precursors to the oestrogens are androgenic substancesandrostenedione or testosterone. There are three main endogenous oestrogens in humans: Oestradiol, Oestrone and Oestriol (Figure 1). Oestradiol is the most potent and is the principal oestrogen secreted by the ovary $[1,2,5,7]$.

\section{Classification}

Based on the sources Oestrogens are classified as [8-11],

\section{Natural Oestrogens}

Eg: Oestradiol, Oestriol, Oestrone (Figure 1).

\section{Esterified Oestrogens}

Eg Oestradiol valerate, Oestradiol benzoate, Oestradiol dipropionate (Table 1 and Figure 2).<smiles>CC12CCC3c4ccc(O)cc4CCC3C1CCC2=O</smiles>

estrone

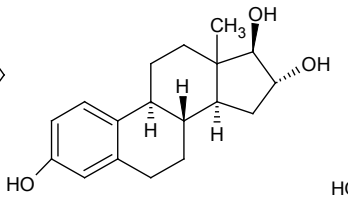

estriol

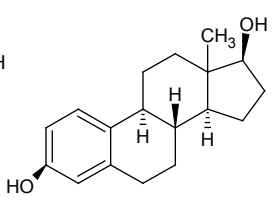

estradiol
Figure 1: Natural Estrogens.

*Corresponding author: Revathi B, Pharmaceutical Chemistry, Osmania University, Hyderabad, Telangana, India, Tel: 91-9533484346, E-mail: revz.pharm@gmail.com

Received February 27, 2015; Accepted April 16, 2015; Published April 20, 2015

Citation: Revathi B, Prashanth K (2015) Anti-Fertility Agents- Estrogens. Med chem 5: 002-R. doi:10.4172/2161-0444.1000002-R

Copyright: $\odot 2015$ Revathi B, et al. This is an open-access article distributed under the terms of the Creative Commons Attribution License, which permits unrestricted use, distribution, and reproduction in any medium, provided the original author and source are credited. 


\begin{tabular}{|c|c|c|c|c|}
\hline S.No. & Compound name & $\mathbf{R}^{\mathbf{1}}$ & $\mathbf{R}^{\mathbf{2}}$ & $\mathbf{R}^{\mathbf{3}}$ \\
\hline 1. & Oestradiol valerate & $\mathrm{H}$ & $-\mathrm{CO}\left(\mathrm{CH}_{2}\right) 3 \mathrm{CH} 3$ & $\mathrm{H}$ \\
\hline 2. & Oestradiol benzoate & $\mathrm{C} 6 \mathrm{H} 5 \mathrm{CO}-$ & $\mathrm{H}$ & $\mathrm{H}$ \\
\hline 3. & Oestradiol dipropionate & $\mathrm{C}_{2} \mathrm{H} 5 \mathrm{CO}-$ & $\mathrm{C}_{2} \mathrm{H} 5 \mathrm{CO}-$ & $\mathrm{H}$ \\
\hline
\end{tabular}

Table 1: Esterified Oestrogens.<smiles>[R7]c1ccc2c(c1)CC[C@H]1[C@@H](C)[C@@H]2CC[C@]1([R2])O</smiles>

Figure 2: Esterified Oestrogens.

\section{Conjugated Oestrogens}

Eg: Equilin (Figure 3).

\section{Semisynthetic Oestrogens}

Eg: Ethinyl oestradiol, Mestranol (Figure 4) .

\section{Synthetic Oestrogens}

Eg: Dienoestrol, Stilboestrol (Figure 5).

\section{Oestrogens from plants}

Eg: Coumestrol (Figure 6) .

\section{Biosynthesis of oestrogens}

In endocrine tissues, cholesterol is the steroid that is stored and converted to estrogen, progesterone, or androgen when the tissue is stimulated by a gonadotropic hormone. The major pathways for the biosynthesis of sex steroid hormones are summarized below. In the ovary, FSH acts on the preovulatory follicle to stimulate the biosynthesis of estrogens. The thecal cells of the preovulatory follicle convert cholesterol into androgens, whereas the granulosa cells convert androgens to estrogens (Figure 7).

1. Cleavage of the side chain of cholesterol produces pregnenolone (step a), which can then be transformed into progesterone or, via several biosynthetic steps, to the aromatic A ring system found in estrogens.

2. Pregnenolone is converted by $17 \alpha$-hydroxylase to 17a-hydroxypregnenolone (step b), which then proceeds on to the intermediate dehydroepiandrosterone (DHEA) via 17,20-lyase reaction (step e).

3. DHEA is converted by 5 -ene- $3 \beta$-hydroxysteroid dehydrogenase and 3-oxosteroid-4,5-isomerase to the 17-ketosteroid, androstenedione (steps $\mathrm{c}$ and $\mathrm{d}$ ), which is interconvertible with testosterone via $17 \beta$-hydroxysteroid dehydrogenase(step f).

4. The final step in the biosynthesis is the conversion of the C19 androgens to the $\mathrm{C} 18$ estrogens via the loss of the $\mathrm{C} 19$ angular methyl group and aromatization of ring A to form $17 \beta$-estradiol or estrone (step g) catalyzed by aromatase.

5 . The interconversion of $17 \beta$-estradiol and estrone is catalyzed by estradiol dehydrogenase (step h), a member of the $17 \beta$-hydroxysteroid dehydrogenase family.

\section{Mechanism of action}

Oestrogen binds to intracellular receptors. There are two types of oestrogen receptor, termed as ER $\alpha$ and ER $\beta$. When oestradiol binds to the estrogen receptor, a conformational change of the estradiolreceptor complex occurs and results in interactions of the estradiolreceptor complex with particular HRE regions of the cellular DNA, referred to as estrogen responsive elements (EREs) [1,12]. Binding of the complex to ERE elements results in initiation of transcription of the DNA sequence to produce mRNA. Finally, the elevated levels of mRNA lead to an increase in protein synthesis in the endoplasmic reticulum. Estrogens produce their effects upon the mammalian uterus by increasing synthesis of RNA in the target cells [13-15].<smiles>CC12CCC3C(=CCc4cc(O)ccc43)C1CCC2=O</smiles>

Figure 3: Conjugated Oestrogens.

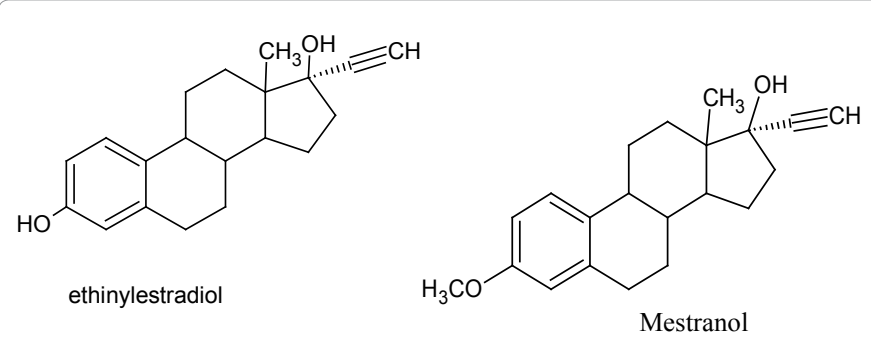

Figure 4: Semisynthetic Oestrogens.<smiles>C/C=C(\Cc1ccc(O)cc1)c1ccc(O)cc1</smiles>

Figure 5: Synthetic Oestrogens.<smiles>O=C1Oc2cc(O)ccc2C2Oc3cc(O)ccc3C12</smiles>

Figure 6: Oestrogens from plants. 


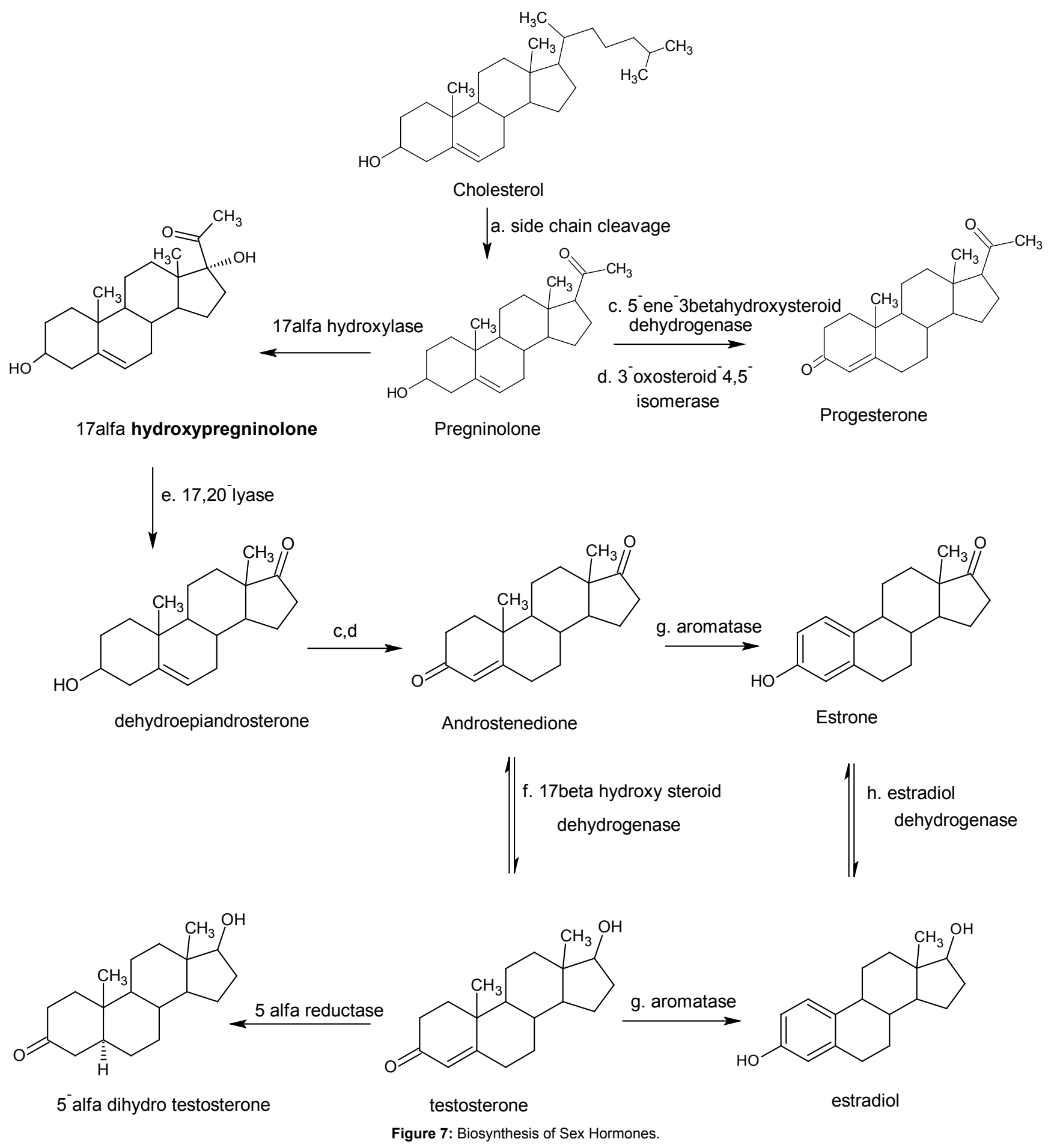

\section{Physiological actions}

Oestrogens act on many tissues such as those of the reproductive tract, breast, and CNS. The primary physiological action of oestrogens is to stimulate the development of secondary sex tissues. They have several metabolic actions including mineralocorticoid (retention of salt and water) and mild anabolic actions [16]. They increase plasma concentrations of high density lipoproteins, a potentially beneficial effect that may contribute to the relatively low risk of atheromatous disease in premenopausal women compared with men of same age. Oestrogens increase the coagulability of blood and contraceptive pills containing a high oestrogen content increase the risk of thromboembolism. This effect is dosing related [17].

\section{Pharmacokinetics}

Natural as well as synthetic oestrogens are well absorbed in the gastrointestinal tract, but after absorption the natural oestrogens are rapidly metabolised in the liver, whereas synthetic oestrogens are degraded less rapidly. Most oestrogens are readily absorbed from skin 
and mucous membranes. They may be given topically in the vagina as creams or pessaries for local effect. In the plasma, natural oestrogens are bound to albumin and to a sex steroid-binding globulin. Natural oestrogens are excreted in the urine as glucuronides and sulfates $[8,9,12,18]$.

\section{Therapeutic uses}

1. These Hormones appear to prevent coronary atherosclerosis in women before menopause because of an alteration in the composition of circulating lipids [2].

2. Because of feminizing effects, estrogen therapy in males is limited.

3. One of the primary therapeutic uses is in the treatment of menopausal symptoms such as hot flashes, chilly sensations, dizziness, fatigue, irritability, and sweating.

4. For many women, menopause does not cause much discomfort; in some, however, both physical and mental discomfort may occur and can usually be prevented through estrogen therapy.

5. One of the most widespread uses of estrogens is in birth control. These hormones are used in postmenopausal osteoporosis because it is thought that an estrogen deficiency in postmenopausal women can lead to this serious disorder of the bone.

\section{Hormone Replacement Therapy:}

Another major use of estrogens is in HRT for postmenopausal women. For this use, a progestin is often included to oppose the effects of estrogens on endometrial tissue $[9,10]$.

7.Treatment of Estrogen Deficiency From Ovarian Failure or After Oophorectomy.

8. Treatment of Advanced, Inoperable Breast Cancer in Men and Postmenopausal Women and of Advanced, Inoperable Prostate Cancer in Men.

\section{Side effects}

1. Nausea appears to be the main side effect; other adverse effects include vomiting, anorexia, and diarrhea.

2. Excessive doses of estrogens inhibit the development of bones in young patients by accelerating epiphyseal closure $[8,19]$.

3. When estrogens are given in large doses over long periods of time, they can inhibit ovulation because of their feedback inhibition of the release of FGH from the adenohypophusis resulting in inhibition of ovulation. Administration of these drugs may promote sodium chloride retention; the result is retention of water and subsequent edema.

4. When administered to males, oestrogens result in feminization.

5. Carcinoma of the vagina was more common in young women whose mothers were given stilbestrol in early pregnancy in a misguided attempt to prevent miscarriage.

\section{SAR of oestrogens}

The naturally occurring estrogens are C18 steroids and contain an aromatic A ring with a hydroxyl group at the 3 position. Substitution of the estrogen steroid nucleus can significantly modify estrogenic activity $[1,10,20]$.

\section{Substitution at ring $\mathrm{A}$ :}

1. The aromatic A ring and the $\mathrm{C} 3$ hydroxyl group are structural features essential for estrogenic activity (Figure 8).

2. Functionality at the $\mathrm{C} 1$ position greatly reduces activity.

3. Only small groups can be accommodated at the 2 and 4 positions.

E.g. 2-hydroxy Ethinyl oestradiol (Figure 9).

\section{Substitution at ring $B$ :}

1. Addition of hydroxyl groups at positions 6,7 and 11 reduces activity.

2. Presence of unsaturation at positions $6^{\text {th }}$ and $7^{\text {th }}$ increase the potency of drug similarly additional double bond between $8^{\text {th }}$ and $9^{\text {th }}$ positions still increases the activity.

E.g. Equilin, Equilenin (Figure 10) .

\section{Substitution at ring $\mathrm{C}$ :}

1. Substituents at the $11 \beta$ position are tolerated; for example,11 $\beta$ methoxy or $11 \beta$-ethyl has significantly greater affinity for the ER as compared to estradiol

2. Substitution of hydroxyl group at $11^{\text {th }}$ position decreases the activity.

\section{Substitution at ring $\mathrm{D}$ :}

1) $17 \beta$ hydroxyl group is essential for oetrogenic activity.

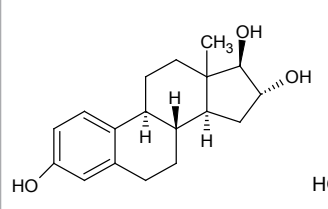

Oestriol<smiles>CC12CCC3c4ccc(O)cc4CC[C@H]3[C@@H]1CCC2=O</smiles>

Oestrone

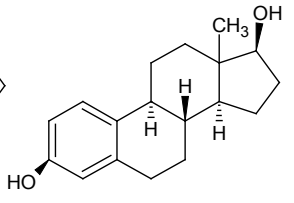

Oestradiol
Figure 8: Oestrogens<smiles>C#C[C@]1(O)CCC2C3CCc4cc(O)c(O)cc4C3CCC21C</smiles>

Figure 9: Substituted Oestradiol.<smiles>CC12CCc3c(ccc4cc(O)ccc34)C1CCC2=O</smiles>

Equilenin<smiles>CC12CCC3C(=CCc4cc(O)ccc43)C1CCC2=O</smiles>

Equilin
Figure 10: Unsaturated Oestrogens. 
<smiles>C#CC1(O)CCC2C3CCc4cc(OC)ccc4C3CCC21C</smiles><smiles>C#C[C@]1(O)CCC2C3CCc4cc(O)ccc4C3CCC21C</smiles>

Mestranol

Ethinyl estradiol

Figure 11: Ethynyl Oestrogens.<smiles>CC12CCC3c4ccc(O)cc4CCC3C1CCCC2O</smiles>

D-homoestradiol

Figure 12: D-Homoestradiol.<smiles>CC/C(=C(/CC)c1ccc(O)cc1)c1ccc(O)cc1</smiles>

Figure 13: Diethylstilbestrol.

2) Removal of the oxygen function from position 3 or 17 , or epimerization of the $17 \beta$-hydroxyl group of

estradiol to the $\alpha$-configuration, results in an estrogenic analogue that is less active.

3) $17 \alpha$-ethynyl or $17 \alpha$-vinyl groups provide the greatest activity.

E.g. Mestranol (Figure 11).

4) Enlargement of the D ring greatly reduces estrogenic activity (Figure 12).

\section{Eg. D-Homoestradiol}

5) The 17 $\beta$-hydroxyl, the distance between the $\mathrm{C} 3$ and $\mathrm{C} 17$ hydroxyl groups, and the presence of planar hydrophobic molecules also are important structural contributors and help to optimize estrogenic activity. Ideally, the distance between the oxygen atoms of the $\mathrm{C} 3$ and C17 hydroxyl groups should range from 10.3 to 12.1 A (Figure 13), Eg: Diethylstilbestrol.

\section{Conclusion}

The importance of Oestrogens has been discussed. The role of estrogens in contraception, their mechanism of action has been discussed. The structures of estrogens were depicted using ChemDraw software.

\section{References}

1. Lemke TL, Williams DA, Roche VF, Zito SW (2008) Foye's principles of medicinal chemistry. $6^{\text {th }}$ ed. New Delhi: Wolters Kluwer/Lippincott Williams \& Wilkins.

2. Block JH, Beale JM (2004) Wilson and Gisvold's text book of organic medicinal and pharmaceutical chemistry. $11^{\text {th }}$ ed. Baltimore: Lippincott Williams \& Wilkins.

3. Abraham DJ (Ed.) (2007) Burger's Medicinal chemistry and drug discovery. $6^{\text {th }}$ ed. Vol 1-6. New Jersy: John Wiely \& Sons.

4. Finar IL (2006) Organic Chemistry-stereochemistry and the chemistry of natural products. $5^{\text {th }}$ ed. Vol 2. Delhi; Doring Kindersley (India) Pvt.Ltd.

5. Rang HP, Dale MM, Ritter JM, Moore PK (2003) Pharmacology. $5^{\text {th }}$ ed Edinburgh: Churchill Livingstone.

6. Ilango K, Valentina (2007) Text book of Medicinal Chemistry $1^{\text {st }}$ Ed. Vol-2. Chennai: Keerthi publishers.

7. Maia, Hugo; Haddad, Clarice; Casoy, Julio (2014) The effect of pycnogenol on patients with dysmenorrhea using low-dose oral contraceptives. Science gov. 01.

8. The Canadian Consensus Conference on Menopause and Osteoporosis (2002) Canada

9. Estrogen and Progestin (Hormone Replacement Therapy) (2015) USA.

10. Hannaford, P. C.; Kay, C. R. (1998) The risk of serious illness among oral contraceptive users: evidence from the RCGP's oral contraceptive study. European research 1: 01.

11. Ryan KJ (1982) Biochemistry of aromatase: significance to female reproductive physiology. Cancer Res. 42 : 3342-3344.

12. Mechoulam R, Brueggemeier RW, Denlinger DL (2025) Estrogens in insects. Cellular and Molecular Life Sciences 40: 942-944.

13. Nelson LR, Bulun SE (2001) Estrogen production and action. J. Am. Acad Dermatol. 45: 116-24.

14. Oh DM, Phillips, TJ (2006). Sex Hormones and Wound Healing. Wounds 18 8-18.

15. Prossnitz ER, Arterburn JB, Sklar LA (2007). GPR30: A G protein-coupled receptor for estrogen. Mol. Cell. Endocrinol. 265-266: 138-42.

16. Fang H, Tong W, Shi LM, Blair R, Perkins R et.al. (2001) Structure-activity relationships for a large diverse set of natural, synthetic, and environmental estrogens. Chem. Res. Toxicol. 14: 280-94.

17. Zhang H, Xie X, Zhu X, Zhu J, Hao C et.al. (2005) Stimulatory cross-talk between NFAT3 and estrogen receptor in breast cancer cells.J Biol Chem.280:4318843189.

18. J. Raloff (1997) Science News Online : Estrogen's Emerging Manly Alter Ego. Science News.

19. Christensen A, Dewing P, Micevych P (2011) Membrane-initiated estradiol signaling induces spinogenesis required for female sexual receptivity. J Neurosci 31: 17583-17589.

20. Hess RA, Bunick D, Lee KH, Bahr J, Taylor JA et.al. (1997) A role for estrogens in the male reproductive system. Nature 390: 447-8. 